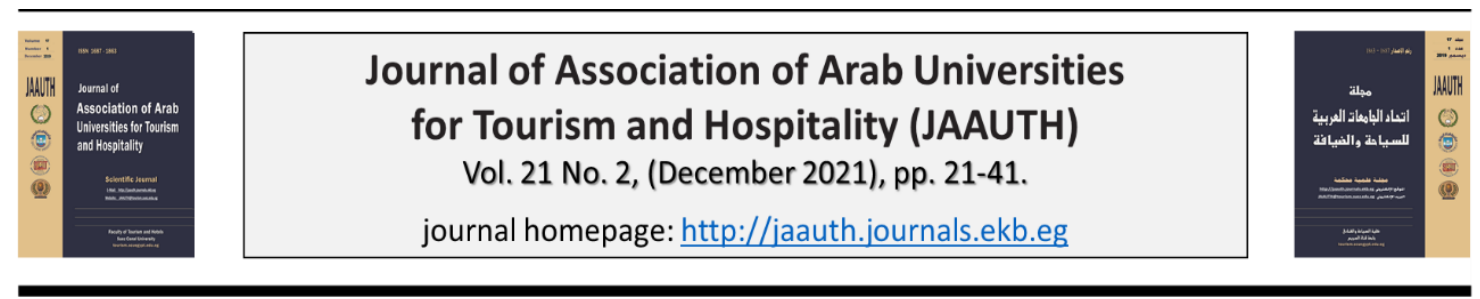

\title{
God Mahes in Ancient Egyptian Religion
}

Mona Ezz Ali

Associate Professor, Faculty of Tourism and Hotels, Mansoura University

\section{ARTICLE INFO ABSTRACT}

Keywords:

Mahes; lion;

Leontopolis.

\section{(JAAUTH) \\ Vol. 21, No. 2, (December 2021), PP.21-41.}

This research deals with one of the minor feline deities, but he was considered a solar god related to wars as he helped the sun god in his war against Apophis, besides he was responsible for guarding the sacred places. He was represented as a lion or a lion-headed god. he was considered as the son of goddess Bastet and god re in Lower Egypt and the son of Sekhmet and Ptah at Upper Egypt, so he was closely associated with god Nefertum(the son of goddess Sekhmet at Memphis). His cult center was at Leontopolis (Taremu), he was worshipped also at Bubastis, Xois, the $10^{\text {th }}$ Nome of Upper Egypt ( $\left.w 3 d t\right)$, Dendera, Edfu, Philae, Dabod, Siwa Oasis and Baharia Oasis. He was associated to many deities like Nefertem, Horus of Behdet, Haroris, Shezmu, Menhw, and Apdemak. The research studies the archaeological and textual evidences of God Mahes referring to his titles, qualities, forms, roles, places of the worship and his relations to other deities.

\section{Introduction}

Lions were worshipped since the Old Kingdom till the end of the Egyptian civilization for its strength and power. Numerous deities appeared in leonine form like Sekhmet, Mut, Menhyt, Mekhit, Mut, Seret, Shesmetet, Pakhet, Tefnut, Mahes, Aker, Apedamak, and Tutu. The lion headed deities were mostly considered as solar deities and so they related to the royalty and kingship, as they were thought to help the sun god in his daily journey, and they helped the kings to attack their enemies. Kings and high officials were shown accompanying lions at their wars and their hunting trips, as they signified the ruler's victory over chaos and rebels and it is clear from their epithets like who slaughter enemies, mighty in his arm, who pursuits the rebels, the god who slaughters to you all foreign lands, and who draw off the blood of enemies. ${ }^{1}$

\section{Leontopolis (Taremu)}

The cult center of God Mahes was in the $11^{\text {th }}$ Nome of Lower Egypt, leontopolis, city of lions, (modern Tell el-Muqdam), it was known in ancient Egypt as $t 3 \mathrm{rmt}$ or $t 3$ $r m w$ which means land of fish, being an important and a plentiful source of fish in the Delta. ${ }^{2}$ It is located in the eastern Delta, about $19 \mathrm{~km}$ northeast of Bubastis. It was probably the capital of the $23^{\text {rd }}$ dynasty .it is now almost completely in ruins. In the eastern part of the city the temple of Mahes was discovered, but most of its blocks were removed and reused in other places ${ }^{3}$ 


\section{Names}

Mahes was called Miysis or mios by the Greeks. m3i hs means "(he who can) see in front". However, the first part of his name $m 3 i$ is "the hieroglyph sign represents the male lion and it means lion, and the word hs means savage, so mi h hs means the savage lion or a lion with terrible look reflecting his nature. However, the first glyph $m 3 i$ also is part of the glyph for $m 3 x t$, so he is considered as a helper for the justice goddess, so Mahes was considered as the devourer of the guilty and it is clear from scenes and statues representing him while devouring the enemies. ${ }^{4}$

The name of $m 3 i h s$ is stated in pyramid texts $38 \stackrel{8}{8} 5$ and coffin texts 3 , but it refers to a lion as an animal not to the lion god Mahes, as the worship of this god didn't appear until the Middle Kingdom, as the name of god Mahes was stated for the first time in htp di nsw formula dating to the late of $13^{\text {th }}$ dynasty ${ }^{7}$ in contrast to the opinion which said that Mahes was stated for the first time in the story of "Taking of Joppa" which dates back to the New Kingdom, where Tuthmoses III was addressed as god Mahes, son of Sekhmet

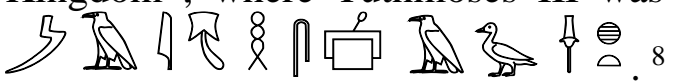

Name of god Mahes was written in different ideograms through the different Periods

During New Kingdom his name was engraved in the following form:

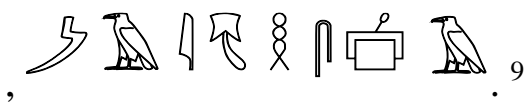

During late Period his name was engraved in the following form:

3.

During Greco - Roman Period his name was engraved in the following forms

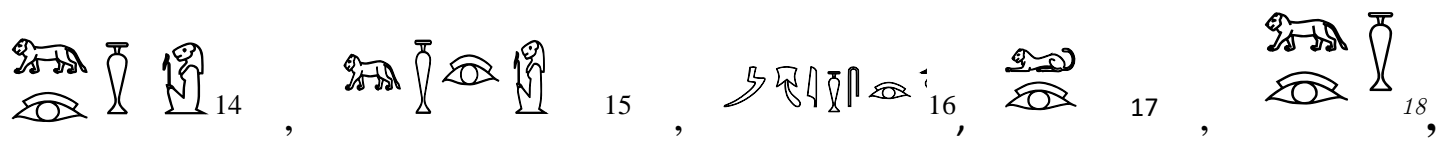

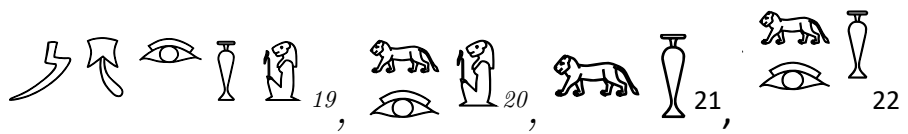

Scenes and Statues of God Mahes: ${ }^{23}$

\section{A. Human forms}

\section{Doc. 1}

God Mahes here is standing in front of goddess Hathor. He is represented in a human form, wearing the atef crown raising his two hands in adoring attitude. He is

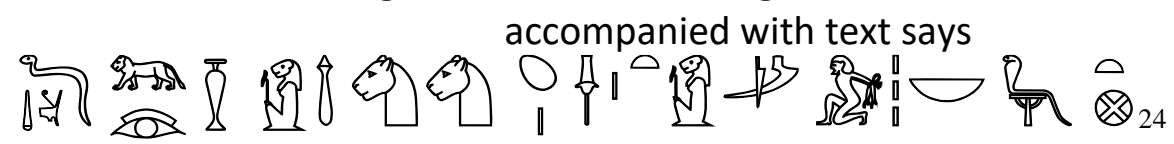


$\underline{d}$ d m $\underline{d} w$ in m3i hss e3 phty s3 shmt sm3 hftyw nb w3d th" words spoken by Mahes, the Great of Power, Son of Goddess Sekhmet, Who slays the enemies, the Lord of the $10^{\text {th }}$ Nome of Upper, Aphroditopolis(Qau al-Kabir) fig.1

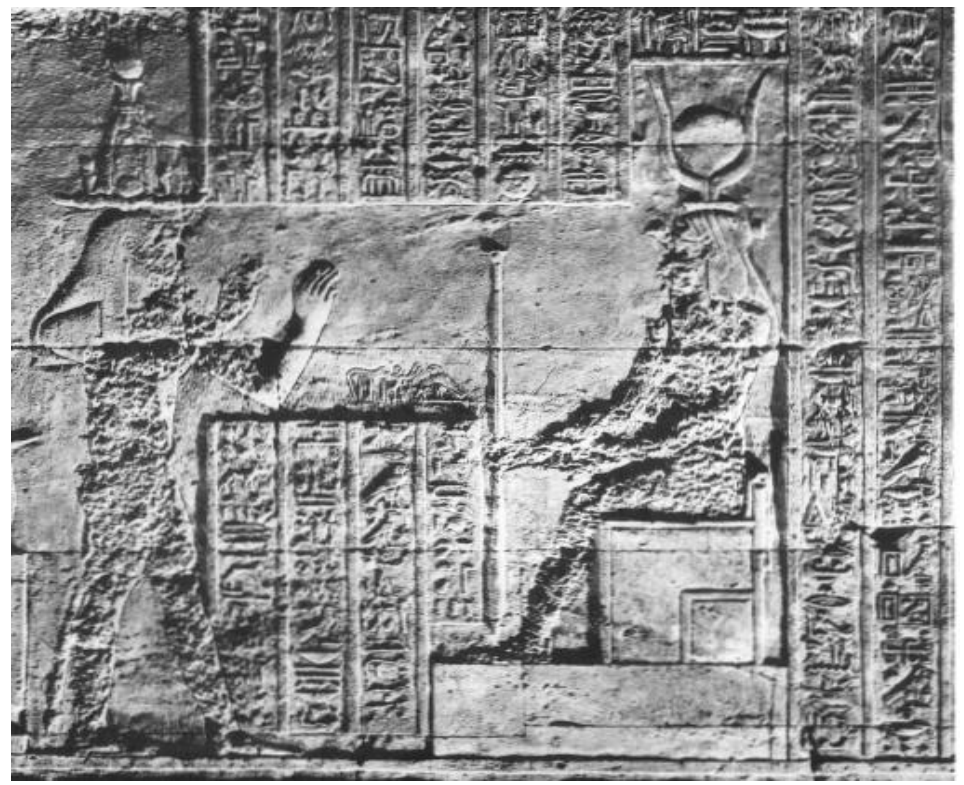

Salle de l'Appartion (Z), Paroi Est, $4^{\text {e }}$ registre, droite, Tableau I.

Fig.1. A scene representing Mahes in a human form wearing the Atef crown, Dendera Temple, Ptolomaic Period

After E. Chassinat, Le temple de Dendara ix, Le Caire, 1978, pl. 844

\section{B.1 A Lion Headed God wearing $n m s$ headdress}

Doc. 2

A Scene represents God Mahes in the form of a standing lion headed God, wearing $n m s$ headdress, holding a knife in his hand ${ }^{25}$ fig. 2

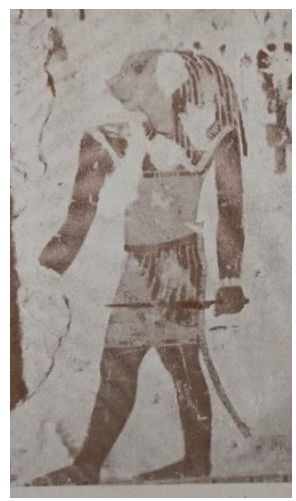

Fig.2. A scene representing Mahes as a lion headed God, wearing nms headdress,

Tomb of si amon, siwa oasis, $26^{\text {th }}$ dynasty.

After A.Fakhry, Siwa Oasis, Cairo, 1944, fig. 29 


\section{B.2 A lion headed God wearing double crown}

\section{Doc. 3}

God Mahes is represented here in a human form with a lion head. He appears in a standing attitude. He wears the double crown upon a tripartite hair wig with the cobra on the forehead. He appears in the same form of the Nubian deities, as he wears dress with two straps hanged to the shoulder with bracelets and armlets. He holds in his hands the $w 3 s$ and the $n h$ sign. He is accompanied with text says

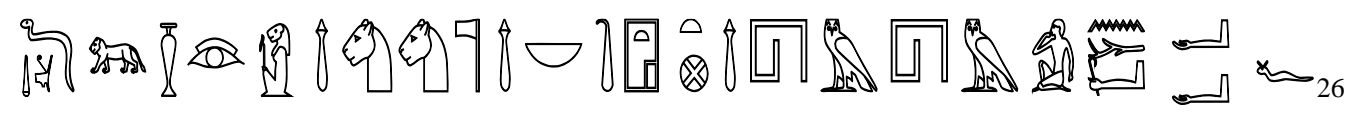

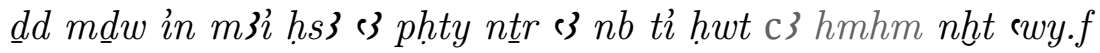

Words spoken by Mahes, the great of power, the great god, lord of Debod, He of the Great Roar, Whose Arms are Strong fig. 3

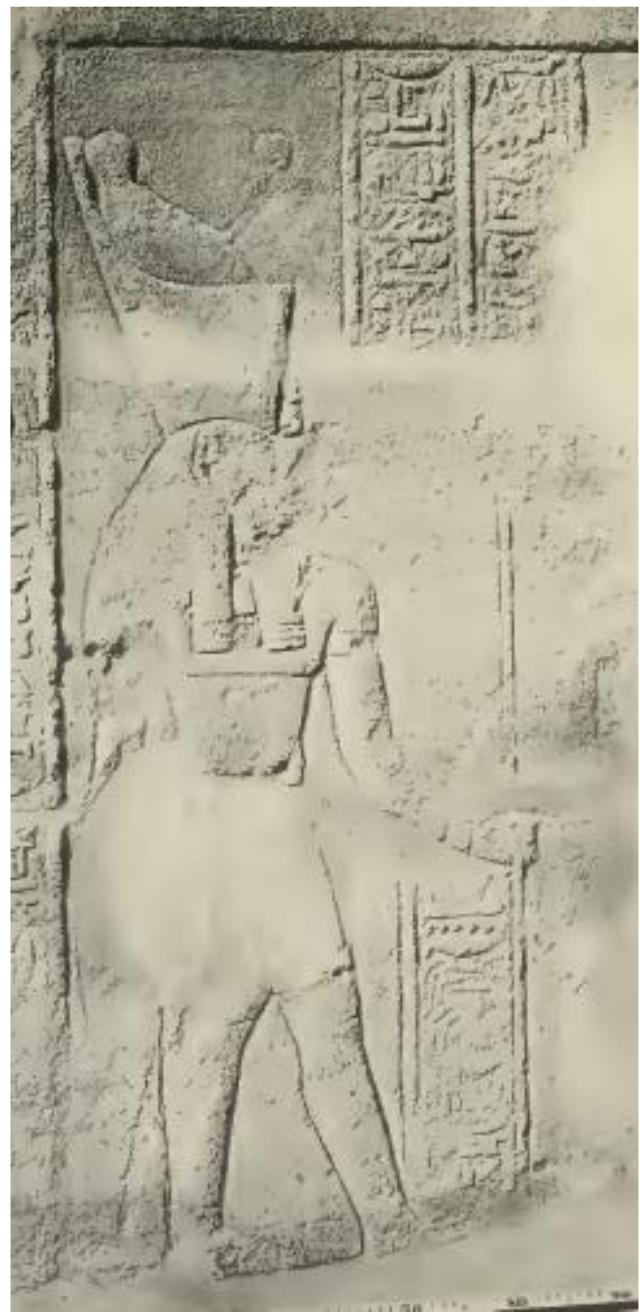

Fig.3. A scene representing Mahes as a lion headed God, wearing double crown, temple of Debod, Ptolomaic Period

After R. Günther, Von Debod bis Bab Kalabsche, Le Caire, 1911 pl. 39, p. 41 


\section{B.3 A lion Headed God wearing Atef Crown}

Doc. 4

Oserkon II in the temple of Bubastis transferred the shape of God Seth to shape of lion god Mahes. He appears here with a lion head wearing the atef crown. He is represented in a sitting attitude wearing the Atef crown and he holds in his hand the w3s scepter. ${ }^{27}$ fig. 4

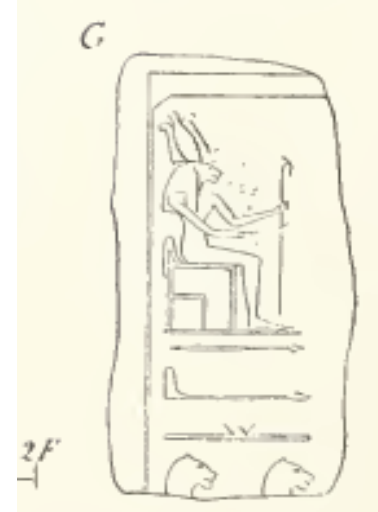

Fig.4. A scene representing Mahes as a lion headed God, wearing Atef crown, Bubastis temple, $22^{\text {nd }}$ dynasty After E. Naville, Bubastis (1887-1889), London, 1891, pl. xlii g

Doc. 5

King Amasis is represented in a standing attitude while offering to Mahes in a scene decorated the hall of chapel of $d d h n s w . f$ $n h$ at Ain El muftella, Baharia oasis. Amasis here wears the Atef crown and a short kilt. god Mahes appears here as a lion headed god wearing the double crown with the cobra on the forehead. He holds in his hands the $w 3 s$ and the $n h h$ sign. He is a ccompanied with his name $h s{ }^{28}$ fig.5

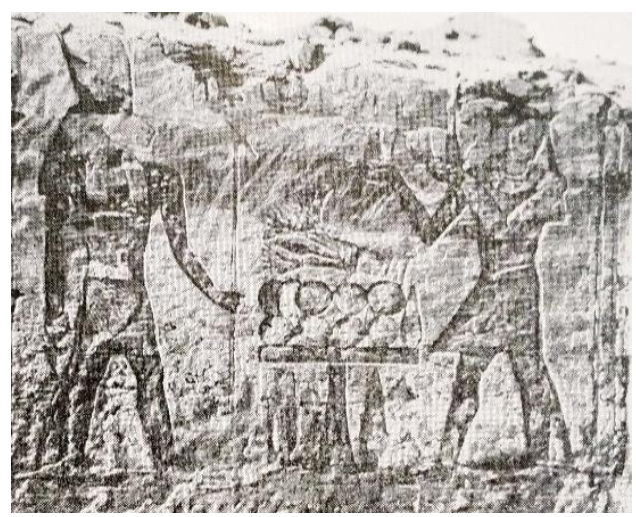

Fig.5. Amasis is standing while offering to Mahes and Bastet, entrance of the hall of chapel of $d d h n s w . f$ enh at Ain El muftella, Baharia oasis, $26^{\text {th }}$ dynasty

After A. Fakhry, Baharia Oasis I, Cairo, 1942, pl. 44b 
Doc. 6

God Mahes is represesneted together with goddess Bastet in the Scene decorated the healing statue of a priest of Bubastis, Djedher, louvre E10777. He appears as a lionheaded god. He is represented in a standing attitude, wearing Atef crown and short kilt, holding in one hand the $w 3 s$ scepter and in the other one the ${ }^{n h} \operatorname{sign}^{29}$. Behind him stands goddess sekhmet and in front of them stand three of their priests at Tell Muqdam. The text upon God Mahes and goddess Bastet says

\& Mahes, the great of power., (and ) Bastet, eye of Horus, the lady of Tell Muqdam "31 fig.6

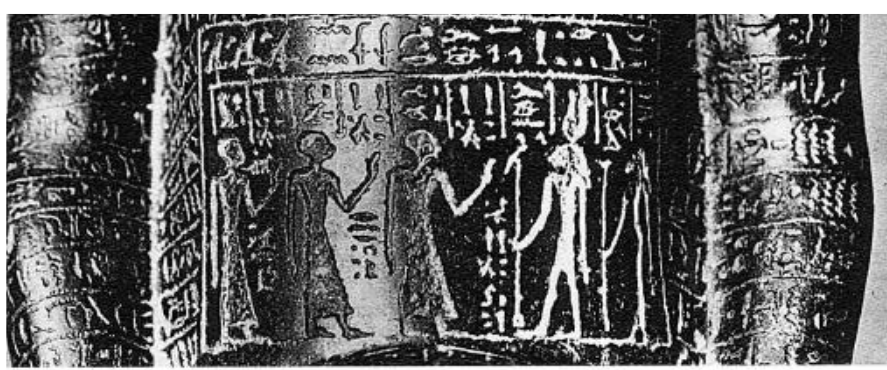

Fig.6. A scene representing Mahes as a lion headed God, wearing Atef crown, statue Louvre E10777", $27^{\text {th }}$ dynasty

After M. Panov, " some notes on the healing statue Louvre E10777", in papers in memory of Tatiana Savelieva, Moscow, 2017, p. 80, pl. 3

Doc. 7

In this stela a priest is represented while making offering (sh3) to God Mahes, who is represented here in the form of a lion headed God wearing atef crown with short kilt, and he holds in one hand the w3s scepter and in the other hand the enh sign. ${ }^{32}$ fig.7

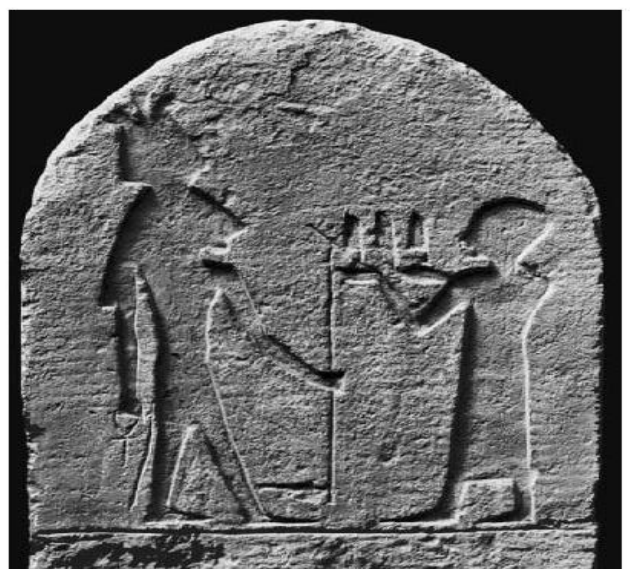

Fig.7. a stela represents a priest making offerings to God Mahes who appears in the form of a lion headed God wearing atef crown, Copenhagen, Ny Carlsberg, AEIN 309, Ptolomaic Period.

After Cl. Willy," Two Ptolemaic Stelae for the Sacred Lion of Leonton Polis (Tell Moqdam)", Chronique d'Égypte 82, 2007, fig. 7 


\section{C.1 A Complete Crouching Lion Holding a Knife between The Frontal Paws}

Doc. 8

Mahes appears in wall of the portico $\mathrm{H}$ of Mammissi of Edfu in the form of crouching lion with knife on its front paw. ${ }^{33}$ fig. 8

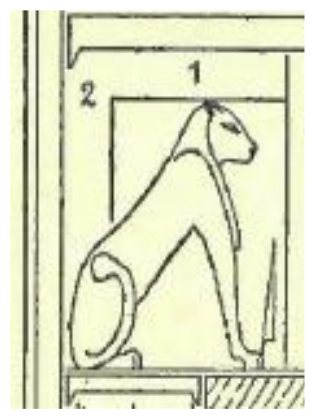

Fig.8. A scene represents Mahes in the form of crouching lion with knife on its front paw Mammissi of Edfu, portico $\mathrm{H}$, Ptolomaic Period

After È. Chassinat, Le Mammisi d'Edfou,Le Caire, 1910, pl. 32

\section{C.2 A Complete Lion Holding A Knife between The Frontal Paws with A Lotus} Flower with two Bud at The back

\section{Doc.9}

In the eastern colonnade of phila temple Mahes appears in the form of crouching lion with knife on its front paw $^{34}$, and its tail ends in two closed and one open lotus flower. ${ }^{35}$ fig. 9

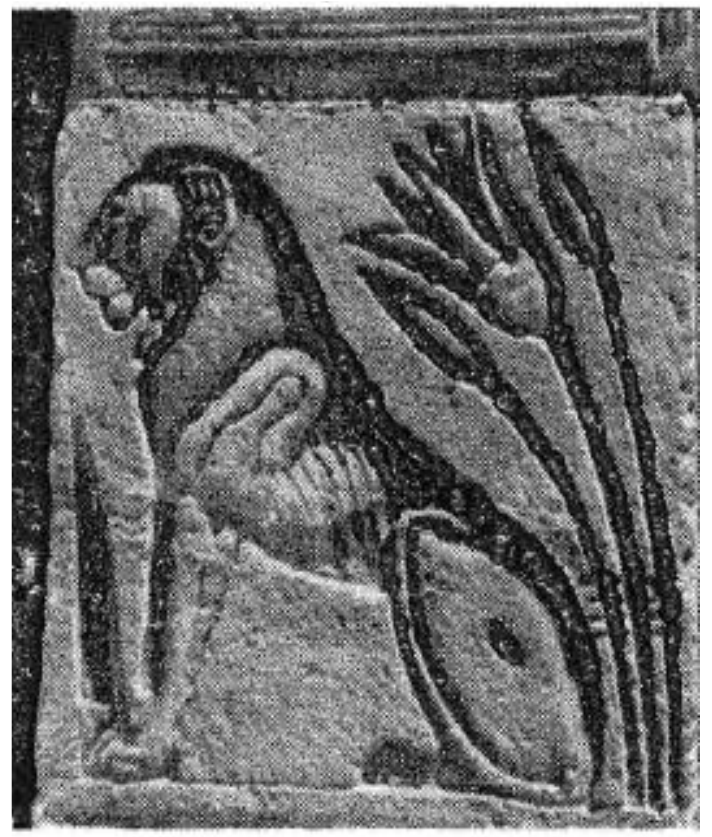

Fig.9. Mahes with tail ends in two closed and one open lotus, Eastern colonnade, northern wall of Philae temple, Ptolomaic Period

A. Varille, " La grande porte du temple d' Apet à Karnak", ASAE 53, le Caire, 1956, fig. 6 


\section{C.3 A Complete Lion Devouring the Tethered Enemy}

Doc. 10

In the naos of Amasis D 29 at louvre museum god Mahes appears as upright lion devouring his standing enemy from his head, and he seizes him from his chest by his frontal legs. ${ }^{36} \mathrm{God}$ Mahes here appears as a huge lion wearing the same headdress of God Nefertem which consists of a lotus blossom and two upright plumes and hanged at its sides two necklace counterpoises. He is accompanied with his name ל) \& $8 \|_{m 3 i} h s^{37}$ fig.10

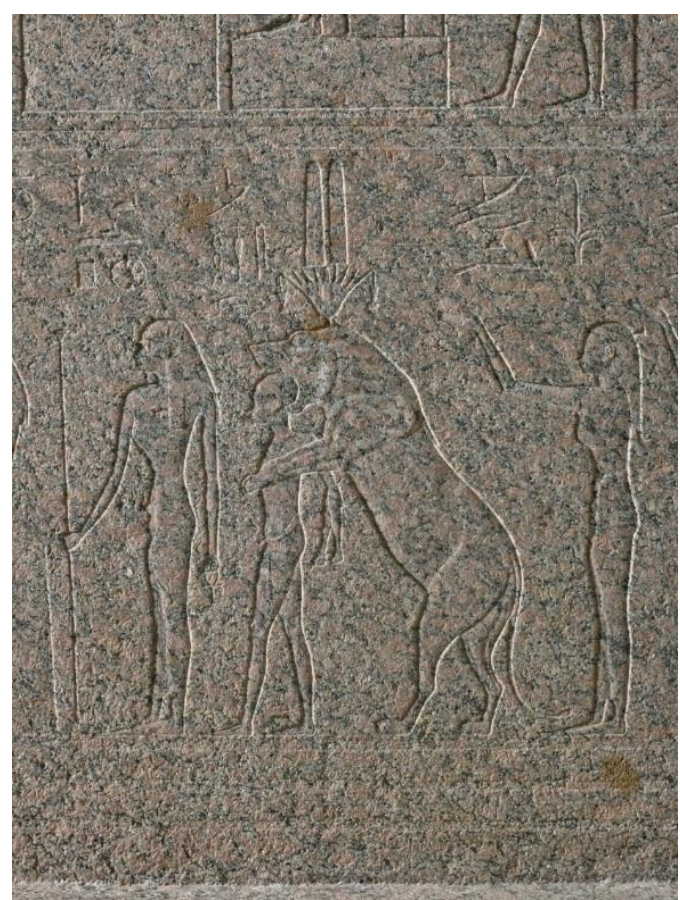

Fig.10. A scene represents Mahes as upright lion devouring a standing man, northern wall of naos D 29 at Louvre Museum, 26 $6^{\text {th }}$ dynasty.

After A. Piankoff, "Le naos D 29 du Musée du Louvre», RdE 1, 1933, p. 161-179 and pl. VIII.

Doc. 11

In the Naos of Saft el Henneh lion god "Mahes" is shown standing on its back legs, attacking an enemy in front of the king, as he captures the seized enemy with his frontal legs and bites his head in the way of devouring him. Upon the head of Mahes stands a falcon bird crowned with the headdress of Nefertem (the lotus blossom, two plumes, and the necklace counterpoises). He is accompanied with his name ל) \& $\|_{m i h s}{ }^{38} \mathrm{fig} .11$ 


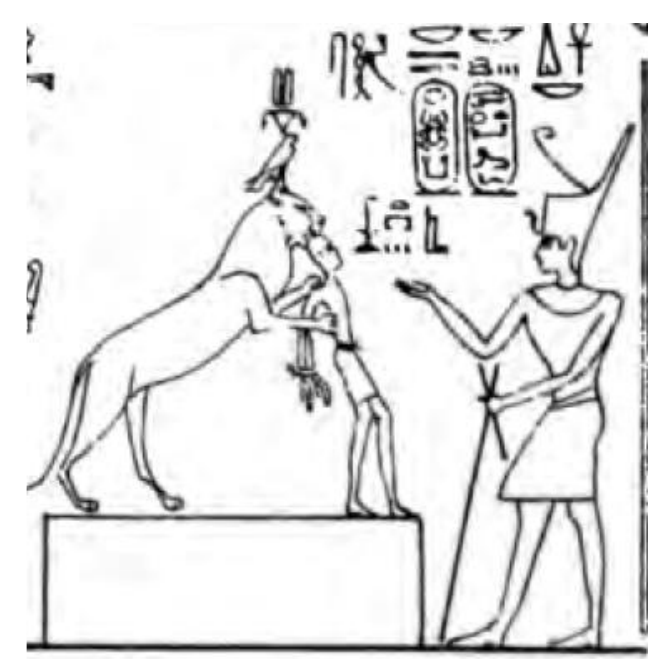

Fig. 11. A scene represents Mahes as A standing lion devouring his enemy in front of the king, the Naos of Saft el Henneh, $27^{\text {th }}$ dynasty

E.Naville, The Shrine of Saft el Henneh and the Land of Goshen (1885). The Egypt

Exploration Society Excavation Memoirs V, (1887), pl.7

\section{C.4 A Lion with Sun Disc and Uraeus over the Head}

Doc. 12

Mahes in this stela is shown as a crouching lion on a pedestal. He appears with a sun disc with the uraeus over his head. He is accompanied with inscriptions say

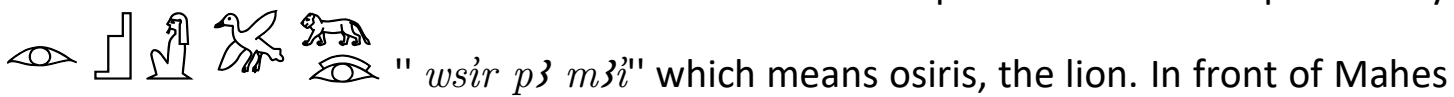
stands a king called "Ptolomy" while offering the $\operatorname{sh} 3$ sign to the lion god Mahes. ${ }^{39}$ fig.12

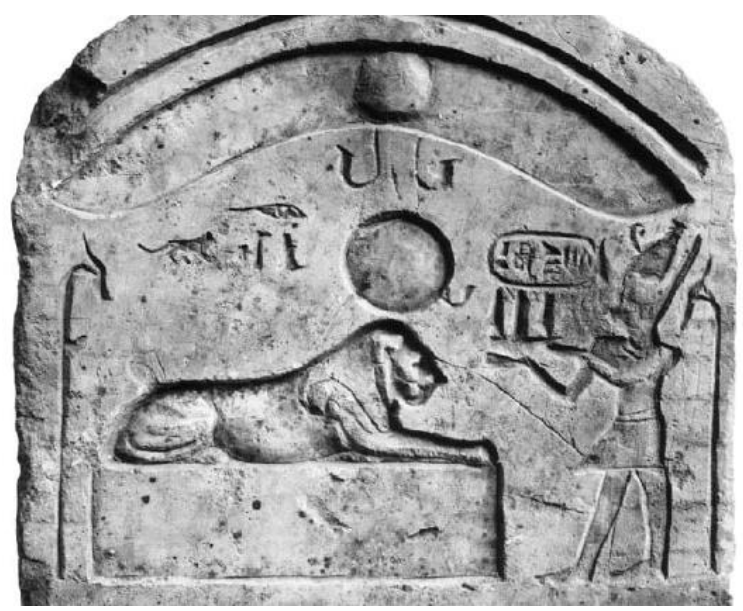

Fig.12. A stela represents god Mahes as a crouching lion on a pedestal, Louvre inv. E 14226, Ptolemaic Period

After Cl. Willy," Two Ptolemaic Stelae for the Sacred Lion of Leonton Polis (Tell Moqdam)", Chronique d'Égypte 82, 2007, fig. 2 


\section{C.5 A Lion Supporting Perfume Jar}

Doc. 13

In the ruins of the temple of God Mahes two statuettes of lion god were found there. Mahes in these statuettes is represented as protecting a sacred jar of the temple. He appears standing on his back paws and grasping the perfume jar with his frontal paws. He is associated here with God Nefertem, god of perfume, who was also responsible for destroying the forces of evil the same as Mahes, who was represented while grasping the enemies with his frontal paws. ${ }^{40}$ (Fig. 13-14)

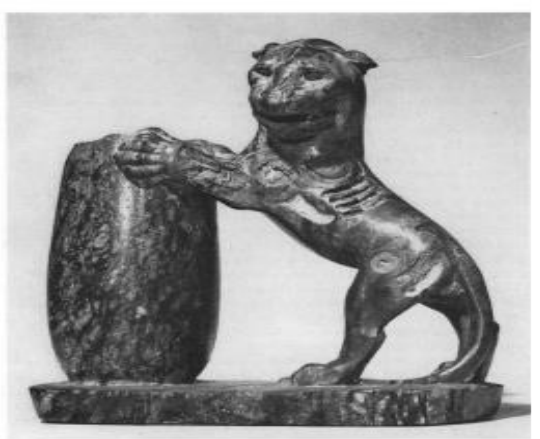

Fig.13. A granite statuette of lion god Mahes protecting a perfume jar, Brooklyn Museum, $27^{\text {th }}$ dynasty

After J.D.Cooney," the lions of Leontopolis", Brooklyn Museum Bulletin ,Vol. 15, No. 2 , (winter, 1954), fig. 1

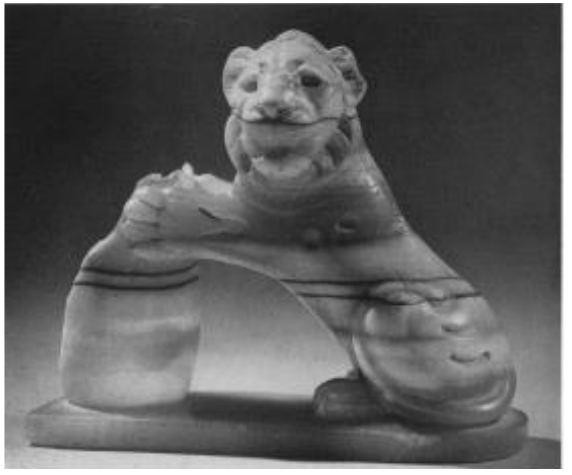

Fig.14. An alabaster statuette of lion god Mahes protecting a perfume jar, Brooklyn Museum, $27^{\text {th }}$ dynasty

After J.D.Cooney," the lions of Leontopolis", Brooklyn Museum Bulletin, Vol. 15,

No. 2 , (winter 1954), fig. 5

\section{Zoomorphic and Anthropomorphic Form}

Doc. 15

Mahes in the stela of hildesheim is shown here twice, once as a lion headed God (anthropomorphic) wearing the Atef crown and the other time as a complete lion (zoomorphic) standing on a high pedestal wearing a solar disc upon its head. ${ }^{41}$ In front of the Mahes the king appears while making offerings. The inscription upon Mahes says 


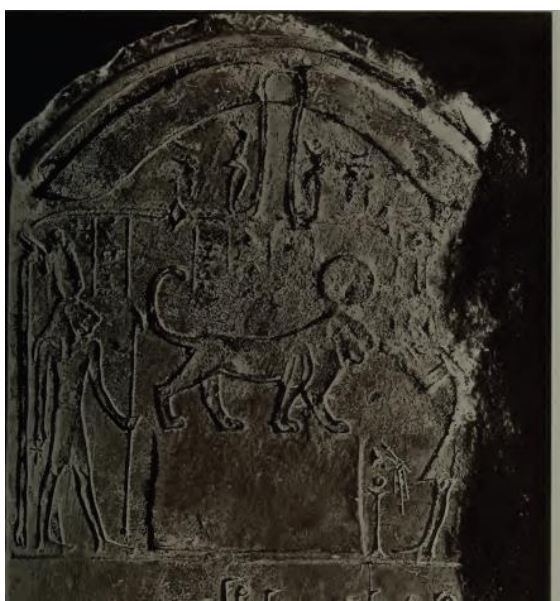

Fig.15. A stela represents Mahes in two forms, once as a lion headed God and other time as a lion standing on a pedestal, Stela of hildesheim, Ptolemaic Period After W. Spiegelberg, " der konigseid des Demotischen papyrus Berlin 3080",

$$
\text { RecTRAV 36, 1914, pl. vii }
$$

\section{Doc. 16}

Mahes in the stela of Switzerland (Äfig 1999.6) is shown like the last stela in two forms, once as a lion with solar disc upon the head and also in a form of a lion headed

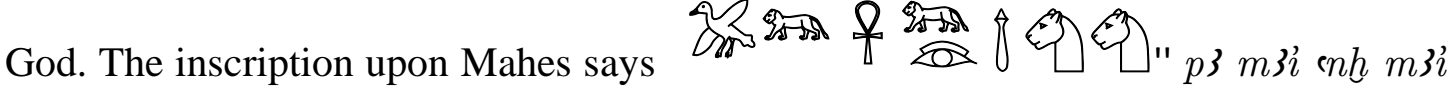
hs 4 phty " the living lion, Mahes the great of power. ${ }^{43}$ The lion here is represeted standing on a tomb in front of the Ptolomic king, who is represented adoring the two forms of Mahes. ${ }^{44}$ fig. 16

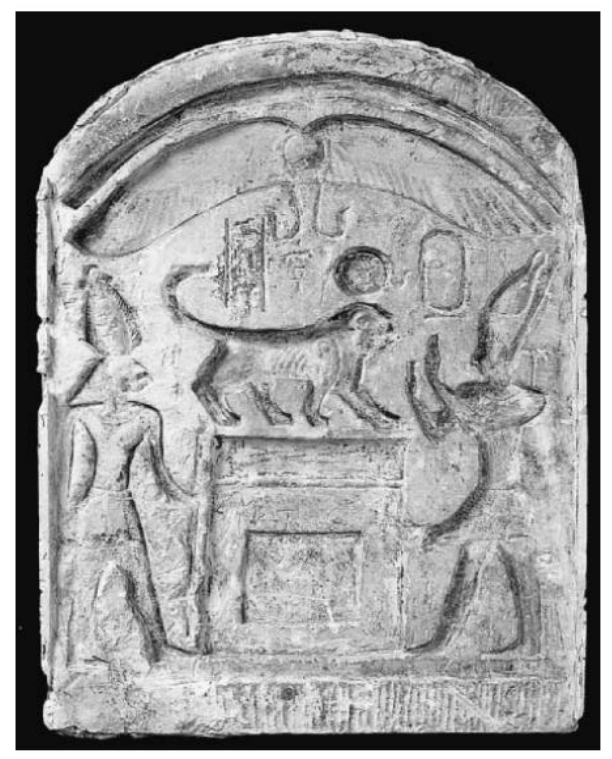

Fig.16. A stela represents Mahes in two forms, once as a lion headed God and other time as a lion standing on a pedestal, Ptolemaic Period

After Cl. Willy," Two Ptolemaic Stelae for the Sacred Lion of Leonton Polis (Tell Moqdam)", Chronique d'Égypte 82, 2007, fig. 15 
Mahes at The Texts

A Text on A satue of the Gardian of the Hall of the Palace, Snefru at Elephantine $\mathrm{N}^{0} 69$, end of $13^{\text {th }}$ Dynasty

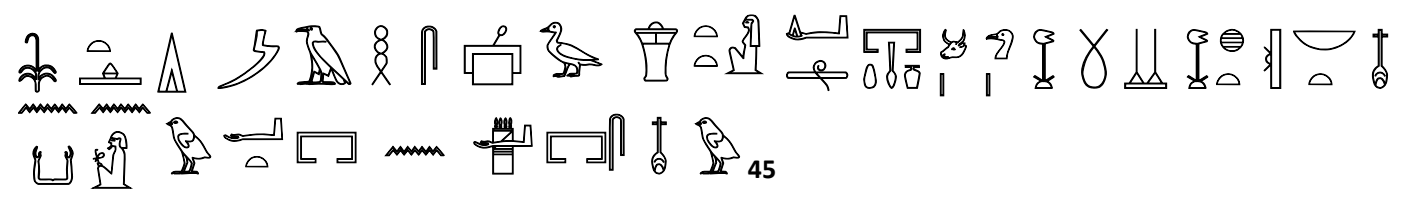

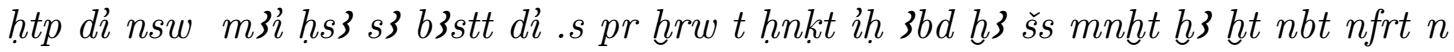
$k 3 n$ s $3 w$ ct $n$ ch

Offering which the king gives to Mahes, son of Bastet, she gives an invocation offering consisting of thousands of bread, beer, meat of oxen and birds, thousands of precious stones and clothes, andevery beautifu things to the gardianof the hall of the palace Snefru

Temple of Oracle at Siwa Oasis, $\mathbf{2 6}^{\text {th }}$ Dynasty

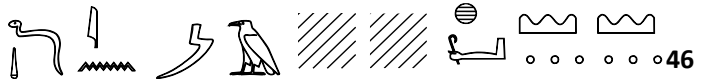

dd $m \underline{d} w$ in $m 3 i$ (hs3) hw ḩsswt

Words spoken by Mahes, the protector of the deserts

The Hall of Chapel of $d d h n s w . f$ enh at Ain El Muftella,Baharia Oases, 26 $^{\text {th }}$ Dynasty

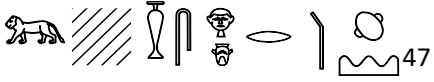

mi his 3 hr ib whist

Mahes who is worshipped in oasis

Papyrus of Bremner- Rhind, Ptolemaic Period

A Spell part of the book of throwing Apophis at papyrus of Bremner-Rhind, in which Mahes faught Apophis ,Re's greatest enemy in the underworld .

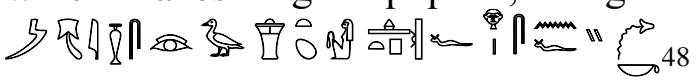

m3i h.s3 s3 b3stt htp. f hrr snfy.k $\mathrm{e} p \mathrm{p}$

Mahes, the son of goddess Bastet, who is satisfied on your blood (apophis )

At the western Pylon of Qous, Ptolemaic Period

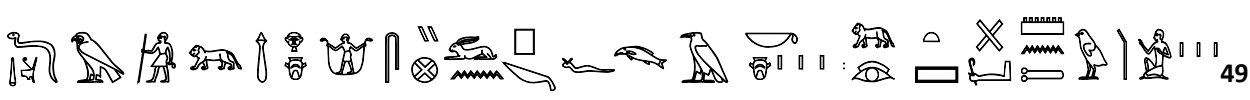

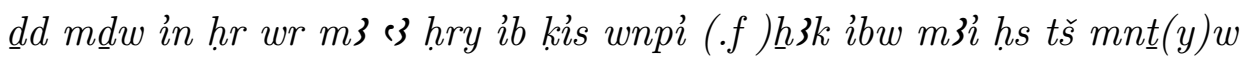

Words spoken by Haroris, the great lion who is worshipped at El Kusiyah(Cusae), he stabs the rebels, Mahes who smashes the beduin of Asia

Sarcophagus of Pennsylvania inv. 16134, Ptolomaic Period

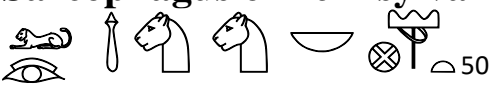

m3i hss es phty nb ḩswt

Mahes, the Great of Strength, lord of Xois 


\section{Dendera Temple, Ptolomaic Period}

*Eastern Staircase.

岛

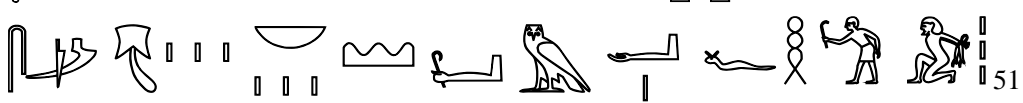

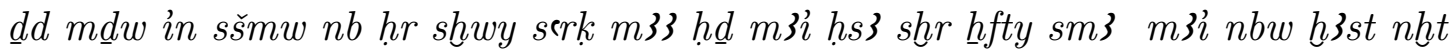
$m$ c.f hwi sbit

Words spoken by shezmu, lord of the slaughterhouse of Horus, who kills the oryx, Mahes who overthrows enemies, who slays all the beasts of the desert, mighty in his arm, who strikes down the rebels

*Eastern Staircase

ये

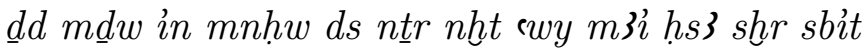

Words spoken by menhw the slayer god, of the strong two arms, Mahes who throw the rebels

\section{Edfu Temple, Ptolomaic Period}

\section{* Offering Hall}

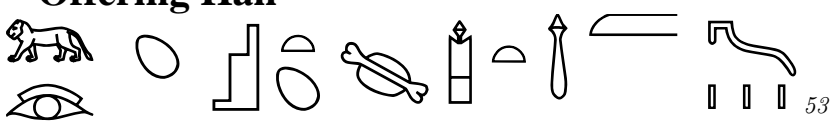

m3 hs s3 ist iwew iwn 3 m stpw

Mahes the son of isis the heir of pillar the great of the selected ones .

*2 $2^{\text {nd }}$ Hypostyle Hall

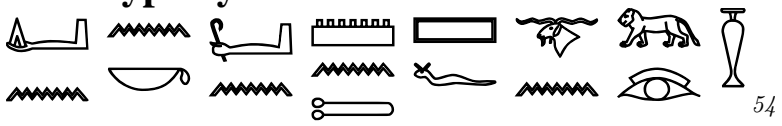

di.n. (i) n.k nht $n$ mntw šfyt $n$ mỉ ḩs

I gave to you (the king) power of mntw and dignity of Mahes

*The Treasure Hall

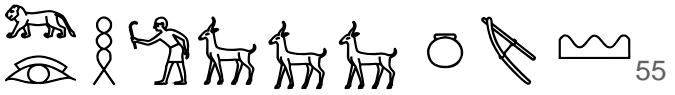

m3 ḥs hwi ghsw nw mrw

He who throws the gazelles of the desert down

*The Pronaos

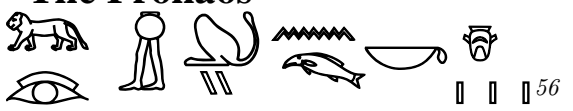

m3 has ini phty n h $3 k i b w$

Mahes who pursuits the rebels 


\section{*The Pronaos}

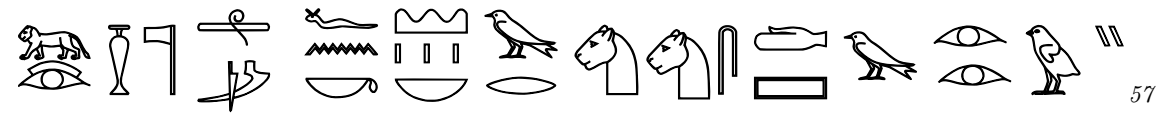

m3i has 3 tr sm3.f .n.k ḩ3swt nb(w) wr phty sdšrt irwy

Mahes the god who slaughters to you all foreign lands, the great of power whose eyes are reddened.

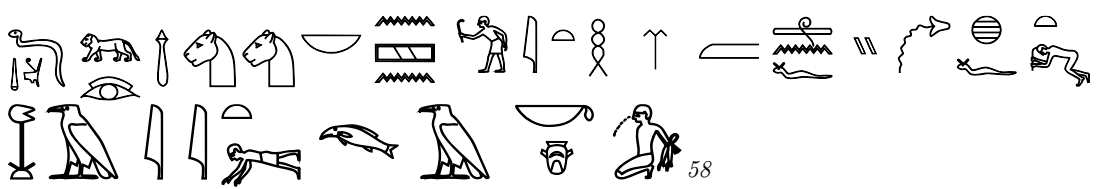

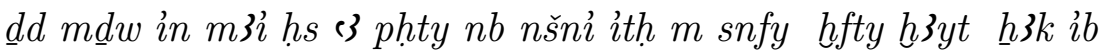
words spoken by Mahes, great of power, lord of storm or rage, who draw off the blood of enemies who slaughter the rebels

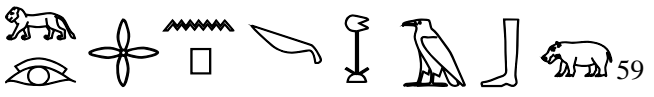

m3i hs wnp h̆3b $m$ š.f

Mahes who kills the hippopotamus in his lake

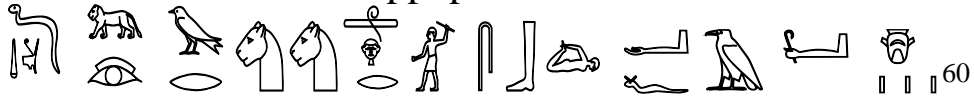

dd malw in m3i has 3 wr phty shre sbi cf3 ibw

Words spoken by Mahes, the great of power, who drives away the rebels and devours the hearts

\section{*The Court}

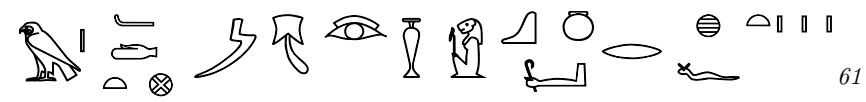

hr bhdt mi m3i hs kni $r$ h̆fiw

Horus of behedet like Mahes, who is strong against the enemies

The court of the edfu temple:

雨

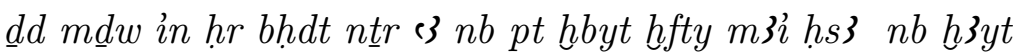

Words spoken by Horus of Behdet, the great god, lord of the sky, who slaughter the enemies like Mahes, lord of slaughter.

\section{*External Part of the Enclosure Wall:}

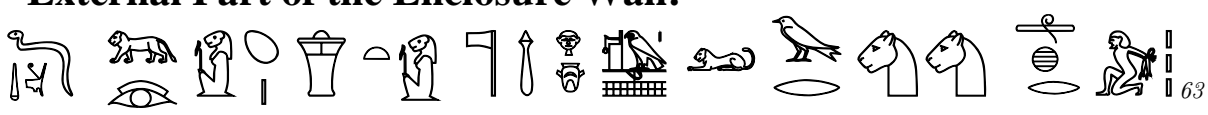

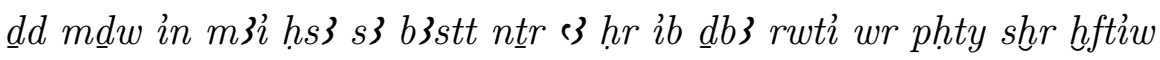

Words spoken by Mahes, son of Bastet, the great god, who is worshipped in Edfu , the lion who is great of power, who overthrows the enemies 


\section{Northern Corridor of Kom ombo Temple, Ptolomaic Period}

管的

$m 3 i$ hs nb $\check{3} n$ b3st

Mahes the lord of the farm of Bubastis

\section{Esna Temple, Ptolomaic Period}

\section{*Column F}

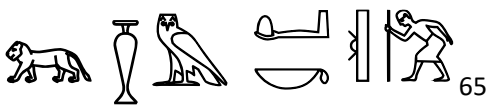

m3 hs mki smsw

Mahes protects the wise men (the eldest)

\section{Dakke Temple, Ptolomaic Period}

*Northern Wall of the Sanctuary:

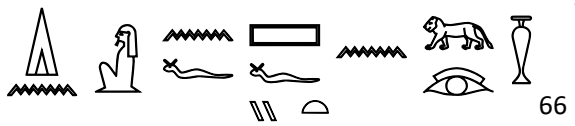

di.n.i( n.f) šfyt (n) m3i hs

I give to(him) the dignity of Mahes

\section{Titles}

From the previous studied scenes and texts, it is concluded that god Mahes carried many titles like:

c3 phty s3 shmt sm3 hftyw nb w3dt" the great of power, son of goddess Sekhmet, who slays the enemies, the lord of the $10^{\text {th }}$ Nome of upper Egypt , Aphroditopolis(Qau al-Kabir) ${ }^{67}$

ntr c3 nb ti hwwt c3 hmhm nht swy.f the great god, lord of Debod, He of the great roar, Whose Arms are Strong 68

$h w$ h3swt Mahes, the protector of the deserts ${ }^{69}$

$h r i b$ wh $3 t$ who is worshipped in oasis ${ }^{70}$

s3 b3stt htp. $f$ hr snfy.k $е p e p$ the son of goddess Bastet, who is satisfied on your blood (apophis ) ${ }^{71}$

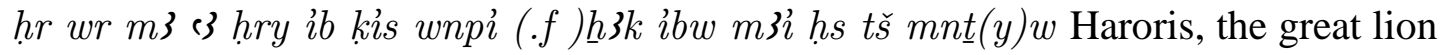
who is worshipped at El kusiyah(Cusae), he stabs the rebels, Mahes who smashes the beduin of Asia 72

$n b$ ḩsswt lord of Xois ${ }^{73}$

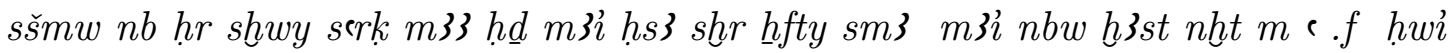
sbit shezmu, lord of the slaughterhouse of Horus, who kills the oryx, Mahes who overthrows enemies, who slays all the beasts of the desert, mighty in his arm, who strikes down the rebels ${ }^{74}$ 
mnhw ds ntr nht ewy m3i hs3 shr sbit menhw the slayer god, of the strong two arms , Mahes who throw the rebels 75

m3 hs s3 ist iwew iwn 4 m stpw Mahes the son of isis the heir of pillar the great of the selected ones . ${ }^{76}$

hwi ghsw nw mrw $^{77}$ He who throws the gazelles of the desert down

ini phty $n \underline{h} 3 k i b w \quad$ who pursuits the rebels ${ }^{78}$

m3i hss $n \underline{t r}$ sm3.f .n.k ḩ3swt nb(w) wr phty sdšrt irwy the god who slaughters to you all foreign lands, the great of power whose eyes are reddened. ${ }^{79}$

nb nšni ith m snfy hfty ḩ3yt h $3 k$ ib lord of storm or rage, who draw off the blood of enemies who slaughter the rebels ${ }^{80}$

m3i h̆s wnp ḩзb $m$ š.f Mahes who kills the hippopotamus in his lake ${ }^{81}$

wr phty shr sbi of $i b w$ the great of power, who drives away the rebels and devours the hearts 82

hr bhdt m3i hs kni $r$ hfiw Horus of Behedet, Mahes, who is strong against the enemies ${ }^{83}$

hr bhdt ntr e3 nb pt hbyt hfty m3i hs3 nb ḩ3yt Horus of Behdet, the great god, lord of the sky, who slaughter the enemies ,Mahes, lord of slaughter.

hr ib $\underline{d} b 3$ rwti wr phty shr hftiw who is worshipped in Edfu, the lion who is great of power, who overthrows the enemies ${ }^{85}$

$m 3 i$ hs $n b \check{s} 3 n$ b3st the lord of the farm of Bubastis ${ }^{86}$

mki smsw who protects the wise men (the eldest) ${ }^{87}$

\section{His Qualities}

It is concluded from the titles and the studied texts that this god is characterized with the following qualities:

Mighty god and god of war : Mahes was one of the lion headed gods who was known with his strength and his great ability as he was represented sometimes while devouring his enemy and also while holding the knife in his hand and most of his titles refer to his strength like the great of power, son of goddess Sekhmet, who slays the enemies, He of the great roar, Whose Arms are Strong, who is satisfied on your blood (apophis ), who smashes the beduin of Asia, lord of the slaughterhouse of Horus, who kills the oryx,who overthrows enemies, who slays all the beasts of the desert, mighty in his arm, He who throws the gazelles of the desert down, who pursuits the rebels, the god who slaughters to you all foreign lands, the great of power whose eyes are reddened, lord of storm or rage, who draw off the blood of enemies who slaughter the rebels, who kills the hippopotamus in his lake, the great of power, who drives away the rebels and devours the hearts, who is strong against the enemies , lord of slaughter. 
A Protecting God: He helped and protect king from his enemies and the rebels, and he protected Re in the underworld from his greatest enemy, apophis, he protected also the eldest and wise men and it is obivious from his titles the protector of the deserts, Mahes who throw the rebels, who pursuits the rebels, the god who slaughters to you all foreign lands, who protects the wise men (the eldest)

A Solar God : he was considered sometimes as the son of the sun god, Re , and goddess Bastet. Owing to this relation to the sun god, he was sometimes depicted with the solar disk and uraeus on his head, and he protected Re in the underworld from his greatest enemy, apophis, and it is clear from his epithet as who is satisfied on your blood (apophis)

A Weather god: he associated with weather as he carried the title of lord of storm

The Worship Places of Mahes

Tell Muqdam: it was the main cult center of Mahes and he carried title of lord of Tell Muqdam nb t3 mrw

Tell Bast: he carried the title of the lord of the farm of Bubastis $n b \check{s} 3 n$ b3st"

Qau al-Kabir: he carried title of the lord of the $10^{\text {th }}$ Nome of Upper Egypt (Qau alKabir) $n b$ w $\underline{d}$ dyt"

Debod: he carried title of the lord of Debod $n b$ ti hwwt

Edfu: he carried title of who is worshipped in Edfu $h r i b \underline{d} b 3$

Xois: he carried title of lord of Xois $n b$ ḩswt

Oasis: he carried title of who is worshipped in oasis $h r$ ib whit

El Kusiyah(Cusae): he carried title of who is worshipped at El Kusiyah(Cusae) hry ib kis

He appeared also in scenes decorated temples of Dendera, Esna, and Philae.

\section{Assimilation and Relation with other Ddeities}

From the studied texts and scenes. It is concluded that he was associated and assimilated with many deities like the following deities

Horus of Behedet : Mahes is ssociated with Horus of Behedet whose cult center was at Edfu and carried title of Horus of Behdet Mahes, who is strong against the enemies and Horus of Behdet, the great god, lord of the sky, who slaughter the enemies ,Mahes, lord of slaughter, who is worshipped in Edfu , the lion who is great of power, who overthrows the enemies.

Horus the elder (Haroris): Mahes is ssociated with Haroris who is worshipped at Kusiyah and carried the title Haroris (the great lion who is worshipped at El kusiyah (Cusae), he stabs the rebels, Mahes who smashes the Beduin of Asia

Shezmu : Mahes is ssociated with tle lion god Shezmu, as he carrried the title Shezmu lord of the slaughterhouse of Horus, who kills the oryx, Mahes who 
overthrows enemies, who slays all the beasts of the desert, mighty in his arm, who strikes down the rebels

Menhw: Mahes is associated with the ion god Menhw as he carried the title ""menhw the slayer god, of the strong two arms , Mahes who throw the rebels"

Sekhmet: Mahes is considered the son of the lionness goddess Sekhmet and he carries the title "Son of Goddess Sekhmet"

Bastet: Mahes is considered the son of goddess Bastet and he carries the title "son of Bastet" in many scenes and they were worshipped together at tell Bast and Tell Muqdam (his cult center) and she carried the title of lady of Tell Muqdam

Nefertem: Mahes is associaated with Nefertem, as both of them are sons of goddess Sekhmet. Mahes appears wearing the headdress of Nefertem fig. 11 and in some scenes he appears with lotus flower and two bud to his back (the symbol of god Nefertem ). Mahes appeared in some statues as a lion protecting the perfume jar relating him with Nerfertem (the god of perfume). Fig. 13-14

Apdemak: there is a great identification between god Apedemak and Mahes in the shape and the function as both of them is known as a warrior, a protective, and a solar god, in addition that the cult of Mahes later spread southwards to Debod ${ }^{88}$

\section{Conclusions and Results}

From this study it is concluded that:

- It is noticed that different forms for the name of Mahes appeared during the Ptolomaic Period.

- The name of Mahes was stated for the first time as a god at htp di nsw formula dating to the end of $13^{\text {th }}$ dynasty, while the word Mahes during Old and Middle Kingdoms was used to refer to a lion not to the god Mahes.

- His cult center was at Leontopolis (Taremu), Bubastis, and Xois at the north. His cult extended towards the south at $10^{\text {th }}$ Nome of Upper Egypt ( $\left.w 3 \underline{d} t\right)$, Dendera, Edfu, Philae, Dabod, and also, he was worshipped at Siwa Oasis and Baharia Oases.

- Mahes carried many titles and epithets. he was considered a war deity, a protective and a solar god

- Mahes appeared in many forms as he appeared some times in a human form, and also in the form of a lion headed god wearing nms headdress, or the double crown , and in many scenes he appeared with the Atef crown, in addition to his representation as a complete lion holding a knife between the frontal paws and sometimes with a lotus flower with two bud at the back, or as a complete lion defouring the tethered enemy or as a lion grasping a perfume jar instead of the enemy reating him to god Nefertem, and he appeared also as a lion with sun disc and uraeus over the head relating him with god Re.

- He is characterised with many qualities as he was considered as a war deity known with his strength which appeared from his epithets and fro his form while holding 
the knife or while devouring his enemy . he was known also as a protective deity for god Re and kings against their enemies and rebels. Besides he was responsible for protecting the sacred places as he was represented as a protective lion at the door ways and jambs of some temples. he was also considered as a solar deity as he appeared with the soar sun disc with cobra upon his head and he protected re from his enemy Apophis, and he was considered as the son of Re and Bastet.

- He was associated and identified with many deities like Horus of Behedet, Haroris, Shezmu, Menhw, Sekhmet, Bastet, Nefertem, Apdemak.

\section{Bibliography}

${ }^{1}$ C. Wit, Le rôle et le sens du lion dans l Égypte ancienne, Leiden, 1957, p. 15

2 J. Yoyotte, La ville de «Taremou » (Tell el-Muqdâm). BIFAO 52 (1952), p. 180

${ }^{3}$ J. Baines, Atlas of Ancient Egypt,Cairo, 2005, p. 172

${ }^{4} \mathrm{~Wb}$ II, 12

${ }^{5}$ pyr. $573 \mathrm{a}$, pt 355 , in this spell the king is described " your tail is that of a lion "

${ }^{6}$ CT VI 192 f, spell 577, p. 182

${ }^{7}$ L. Habachi, Elephantine. The Sanctuary of Heqaib, Mainz am Rhein, 1985, p. 93

${ }^{8}$ GL.V. Zabkar, "Miysis " in Wolfgang Helck and Ebehard Otto, ed., L̈̈ iv, ( Wiesbaden, 1977), col. 163

${ }^{9}$ A. GARDINER, Late-egyptian stories, Bruxelle, 1932, p. 83

${ }^{10}$ A. Fakhry, Baharia Oasis I, Cairo, 1942,p. 155

11 E. Naville, The Shrine of Saft el Henneh and the Land of Goshen (1885), London, 1887 , pl. 7,5

${ }^{12}$ A. Piankoff, «Le naos D 29 du Musée du Louvre», $R d E$ 1, 1933, p. 161-179

${ }^{13}$ A. Fakhry, Baharia Oasis I, Cairo, 1942,p. 153, pl. 44b

${ }^{14}$ È. Chassinat , Le temple de Dendara ix, Le Caire, 1987, p. 63, pl. 844

${ }^{15}$ R. Günther, Von Debod bis Bab Kalabsche, Le Caire, 1911 , p. 41, pl. 39

${ }^{16}$ R.O. Faulkner, The papyrus Bremner-Rhind (British Museum No. 10188), Bruxelle, 1933, 30,24.

${ }^{17}$ G. Lefebvre, " La statue «guérisseuse» du Musée du Louvre", BIFAO 30, p. 95

${ }^{18}$ È. Chassinat, Le Temple d'Edfou II , Le Caire, 1897, p 35

$19 \_$Le Temple d'Edfou V, Le Caire, 1930, p.269

_. Le Temple d'Edfou VII , Le Caire, 1932, p. 163

21 S. Sauneron, Le Temple d Esna, Le Caire, 1963, p. 313

${ }^{22} \mathrm{R}$. Günther, Der Tempel von Dakke, Le Caire, 1930, p. 266

${ }^{23}$ Chr., LEITZ, Lexicon der Ägyptischen Götter und Götterbezeichnung IV, OLA 114, ( Leuven- Paris, 2002, p. 211

${ }^{24}$ È. CHASSINAT , Le temple de Dendara ix, Le Caire, 1987, p. 63, pl. 844

${ }^{25}$ A. Fakhry,Siwa Oasis I, Cairo, 1944,, p. 150, fig. 29

${ }^{26}$ R. Günther, Von Debod bis Bab Kalabsche, Le Caire, 1911 , p. 41, pl. 39

27 E. Naville, Bubastis (1887-1889), London, 1891, pl. xlii g

${ }^{28}$ A. Fakhry, Baharia Oasis I, Cairo, 1942,p. 153, pl. 44b

${ }^{29}$ W. Spiegelberg," Der Konigseid des Demotischen Papyrus Berlin ", Rec Trav 36, 1914,p. 170, pl. viii

${ }^{30}$ G. Lefebvre, " La statue «guérisseuse» du Musée du Louvre", BIFAO 30, p. 95

${ }^{31}$ M. Panov, " some notes on the healing statue Louvre E10777", in papers in memory of Tatiana Savelieva, Moscow, 2017, p. 80, pl. 3

${ }^{32}$ Cl. Willy," Two Ptolemaic Stelae for the Sacred Lion of Leonton Polis (Tell Moqdam)", Chronique d'Égypte 82, 2007, p. 84

33 E. Chassinat, Le Mammisi d'Edfou,Le Caire, 1910, p. 133 
${ }^{34}$ A. Varille, " La grande porte du temple d' Apet à Karnak", ASAE 53, 1956, fig. 6

35 The representation of a symbol of vegetation near the tail of lions or lionesses refers that the earth flourishes, as a result for taming the Enemy, and Seth's fire is defeated when it becomes vegetative, see Ibid., p. 93 .

${ }^{36}$ M.Zecchi, the Naos of Amasis.Amonument for the reawakening of Osiris, PALMA 20 , 2019, p. 143

${ }^{37}$ A. Piankoff, «Le naos D 29 du Musée du Louvre», RdE 1, 1933, p. 161-179

38 E. Naville, The Shrine of Saft el Henneh and the Land of Goshen (1885), London,

1887 , pl. 7,5

${ }^{39}$ Ibid., fig. 2

${ }^{40}$ J.D.Cooney," the lions of Leontopolis", Brooklyn Museum Bulletin, Vol. 15, No. 2 , (winter, 1954), p. 17

${ }^{41}$ This scene assures the Egyptian religious idea which refers that the god can be represented simultaneously in two forms (zoomorphic,anthropomorphic) in which he manifests himself to other beings and to communicate with them to assure the vitality of their deities; L.V.Zabkar, Apedemak, Lion God of Meroe. A Study in Egyptian-Meroitic Syncretism, Warminster, 1975, p. 61

42W. Spiegelberg," der konigseid des demotischen papyrus Berlin ", Rec Trav 36, 1914, p. 175, pl. vii $43 \mathrm{Cl}$. Willy, "Two Ptolemaic Stelae for the Sacred Lion of Leonton Polis (Tell Moqdam)", Chronique d'Égypte 82, 2007, p. 86

${ }^{44}$ Ibid., p. 87, fig. 15

${ }^{45}$ L. Habachi, Elephantine. The Sanctuary of Heqaib, Mainz am Rhein, 1985, p. 93

${ }^{46}$ A. Fakhry,Siwa Oasis I, Cairo, 1944, p. 93

47 ------, Baharia Oasis I, Cairo, 1942,p. 155

${ }^{48}$ R.O. Faulkner, The papyrus Bremner-Rhind (British Museum No. 10188), Bruxelle, 1933, 30,24.

${ }^{49}$ A. Kamal, " Le pylone de Qous", ASAE 3, 1902, p. 231

${ }^{50}$ A. Mariette, Monuments divers recueillis en Egypte et en Nubie, Paris 1872, pl. 63e

${ }^{51}$ È. Chassinat, Le Temple d'Dendera VII , Le Caire, 1978, p.196

52 -

53 -

54 -

${ }^{55}$ Ibid., 291

${ }^{56}$ È. Chassinat,, Le Temple d'Edfou III , Le Caire, 1928, p. 139

57 -

58 --------, Chassinat, Le Temple d'Edfou IV , p.107

${ }^{59}$ Ibid., 117

${ }^{60}$ Ibid., 129

${ }^{61}$ È. Chassinat, Le Temple d'Edfou V, Le Caire, 1930, p.269

${ }^{62}$ Ibid., 296

-----, Le Temple d'Edfou VII , Le Caire, 1932, p. 163

${ }^{64}$ M. Jaques, Catalogue des Monuments et Inscriptions de lÉgypte antique. Haute Égypte. Kom Ombos III, Vienne, 1909, p. 871

${ }^{65}$ S. Sauneron, Le Temple d Esna, Le Caire, 1963, p. 313

${ }^{66}$ R. Günther, Der Tempel von Dakke, Le Caire, 1930, p. 266

${ }^{67}$ È. Chassinat , Le temple de Dendara ix, Le Caire, 1987, p., 63, pl. 844

${ }^{68}$ R. Günther, Von Debod bis Bab Kalabsche, Le Caire, 1911 , p. 41, pl. 39

${ }^{69}$ A. Fakhry,Siwa Oasis I, Cairo, 1944, p. 93

70 -.-----, Baharia Oasis I, Cairo, 1942,p. 155

${ }^{71}$ R.O. Faulkner, The papyrus Bremner-Rhind (British Museum No. 10188), Bruxelle, 1933, 30,24.

72 A. Kamal, " Le pylone de Qous", ASAE 3, 1902, p. 231

${ }^{73}$ A. Mariette, Monuments divers recueillis en Egypte et en Nubie, Paris 1872, pl. 63e

${ }^{74}$ È. Chassinat, Le Temple d'Dendera VII , Le Caire, 1978, p.196

75 -------, Le Temple d'Dendera VIII , Le Caire, 1972, p.196

76 ------, Le Temple d'Edfou I , Le Caire, 1892, p.496

${ }^{77}$ Ibid., 291

${ }^{78}$ È. Chassinat, Le Temple d'Edfou III , Le Caire, 1928, p. 139 
79 ---, Le Temple d'Edfou IV , Le Caire, 1929, p. 271

80 ---------, Le Temple d'Edfou IV , p.107

${ }^{81}$ Ibid., 117

${ }^{82}$ Ibid., 129

${ }^{83}$ È. Chassinat, Le Temple d'Edfou V, Le Caire, 1930, p.269

${ }^{84}$ Ibid., 296

${ }^{85}$ È. Chassinat, Le Temple d'Edfou VII , Le Caire, 1932, p. 163

${ }^{86}$ M. Jaques, Catalogue des monuments et inscriptions de l'Égypte antique. Haute Égypte. Kom Ombos III, Vienne, 1909, p. 871

${ }^{87}$ S. Sauneron, Le Temple d Esna, Le Caire, 1963, p. 313

${ }^{88}$ R. H. WILKINSON, The complete gods and goddesses of Ancient Egypt ,Cairo, 2003, p. 178-179

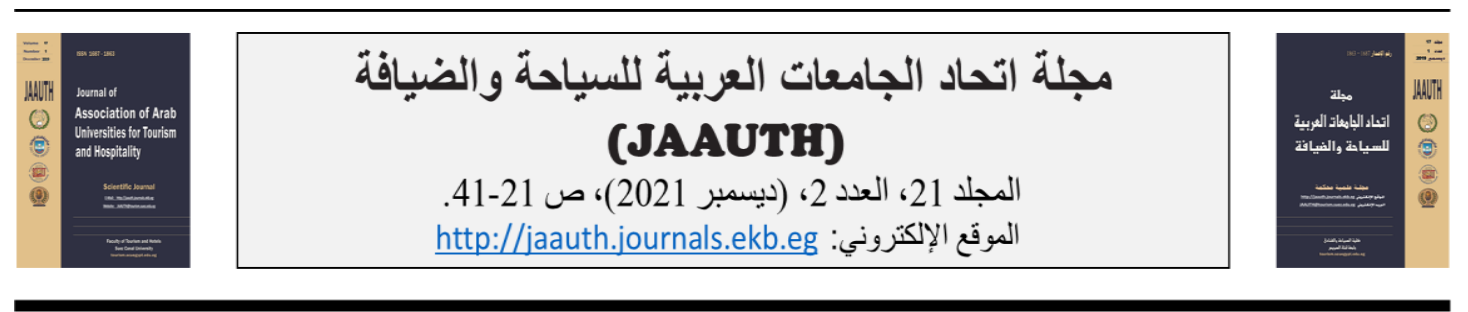

\section{المعبود ماحس في الايانة المصرية القديمة \\ مني عز علي}

أستاذ مساعد، كلية السياحة والفنادق، جامعة المنصورة

\begin{tabular}{|c|c|}
\hline الملخص & معلومات المقالة \\
\hline 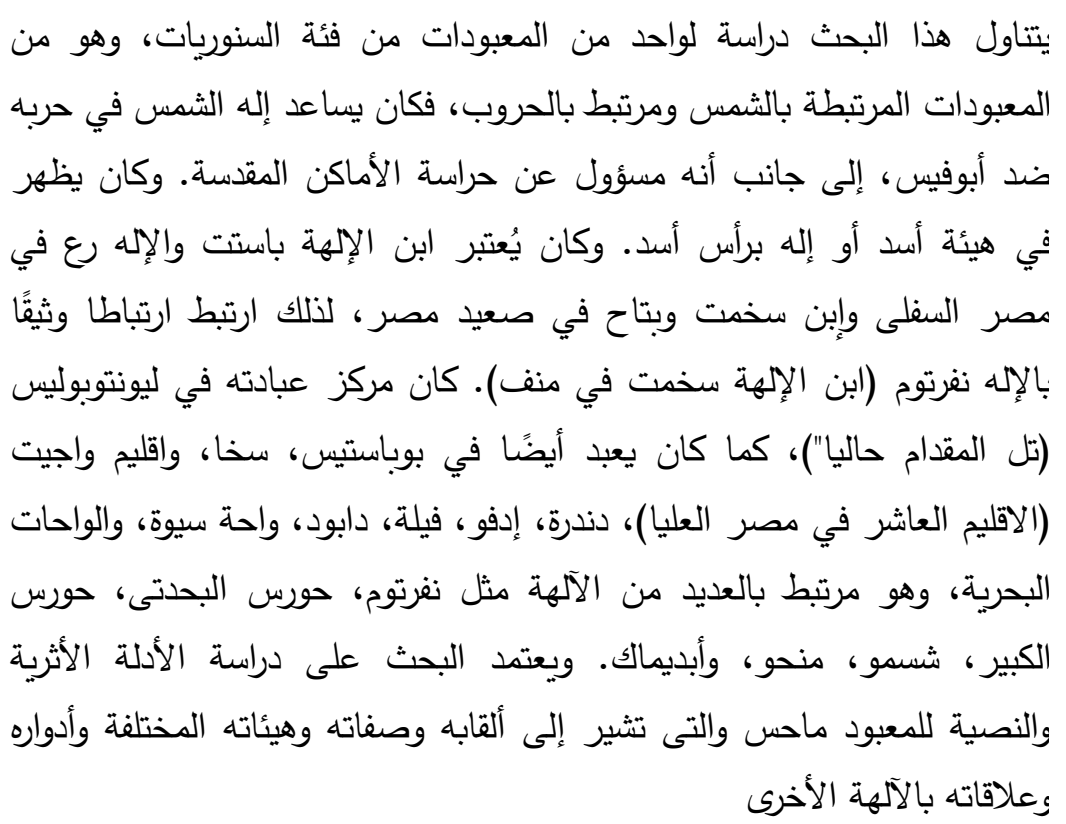 & 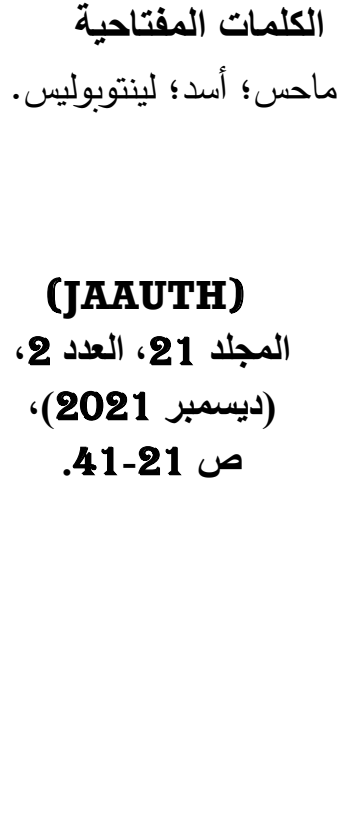 \\
\hline
\end{tabular}

